\title{
How labour made neoliberalism
}

\author{
Elizabeth Humphrys \\ University of Technology Sydney, Australia
}

\section{Damien Cahill}

University of Sydney, Australia

\begin{abstract}
Critical explanations of neoliberalism regularly adhere to a dominant narrative as to the form and implementation of the neoliberal policy revolution, positing neoliberalism in its vanguard period as a project implemented by governments of the New Right, imposed coercively on civil society by state elites and only subsequently adopted by social democratic parties. In such accounts, labour is typically posited as the object and victim of neoliberalising processes. In contrast, this paper focuses upon the active role of labour within the development of neoliberalism. The period of social democratic government in Australia (1983-1996) is used as a case study to illuminate labour's active role in constructing neoliberalism. Indicative evidence from the USA and UK is then presented to argue that the agency of labour can usefully be 'written in' to the presently dominant narrative regarding the rise of neoliberalism to provide a more satisfactory account of its nature and resilience over time.
\end{abstract}

\section{Keywords}

Neoliberalism, Labour, New Right, Australia, United Kingdom, United States 


\section{Introduction}

Critical explanations of neoliberalism often frame the conservative governments of Ronald Reagan and Margaret Thatcher as exemplars of the roll-out of neoliberalism more generally at a global level. This has contributed to a dominant narrative as to the form and implementation of the neoliberal policy revolution. It posits that neoliberalism in its vanguard period was a project of governments of the New Right, imposed coercively on civil society by state elites, and only subsequently adopted by social democratic parties. This dominant narrative has created an ideal type against which scholars view and assess neoliberalism in other locations. In so doing, it has obscured the uneven geographical neoliberal development of neoliberalism by missing specific instances of neoliberalisation that do not fit neatly into this conceptual framing. The dominant narrative emphasises the agency of states and neoliberal intellectuals in the construction of neoliberalism, and casts the role of 'others' — especially labour-as the object and victims of those processes.

Re-examining neoliberalism's origins from the vantage point of the wake of the 2008 economic crisis, helps elucidate how explanations of neoliberalism may have been constrained and limited. This article argues that the dominant interpretive frame has narrowed our understanding of neoliberalism, in particular by ignoring the active role of labour organisations. We examine the role demarcated for labour in the dominant narrative. Within such a narrative, labour is typically viewed as the object of neoliberalism, with states (and New Right governments in particular) typically cast as the active subject. Organised labour is portrayed as the victim, with emphasis placed on the suppression of trade union organising and the intensified exploitation of labour. While agreeing that the neoliberal transformation of states and economies entailed a weakening of the power of organised labour and an increase in the rate of labour exploitation, this paper focuses instead upon the active role of labour, broadly conceived, within this process. This paper argues that the agency of labour can usefully be 'written in' to the present narrative to provide a 
more satisfactory account of the development of neoliberalism in the wake of the collapse of the post-world-war-two economic order.

The analysis is developed in three sections. Section one outlines the dominant narrative and evidences this by examining two influential accounts: David Harvey's $A$ Brief History of Neoliberalism (2005) and Naomi Klein's The Shock Doctrine (2007).

Section two examines a national case study that suggests a contrary narrative: the trajectory of the initial phase of neoliberalism in Australia, between 1983 and 1996. Recent scholarship on neoliberalism from critical social geography and critical international political economy emphasises its 'variegated' (Brenner et al., 2010; Macartney, 2010) nature. By this is meant not simply the uneven geographical development of neoliberalism, which is empirically observable, and, in and of itself, unremarkable. Rather it is to claim that 'neoliberalisation processes' result in ‘systemic production of geoinstitutional differentiation' (Brenner et al., 2010: 184). Indeed, Peck and Theodore argue that 'crucial to understanding neoliberalism... [is] the distinctive spatiality of neoliberalism' (2012: 177). An examination of Australia reveals one such distinct spatiality in the uneven development of neoliberalism. In that location, vanguard neoliberalism was implemented by a social democratic labour government, and in a context of a long-term consensual social contract between the Australian Labor Party (ALP) and the trade union movement. Our analysis emphasises the agency of labour in the neoliberal revolution in Australia. We argue that the organisational leadership of the labour movement and the ALP were the key forces within the state that made neoliberalism in that context, and that this represents a blind-spot in scholarly analyses of neoliberalism of the period, many of which are reluctant to view labour as one of the key agents in the creation of neoliberalism. 
Yet, if there is a variegated character and distinct and constitutive spatiality to neoliberalisation, is it also the case that there is a neoliberal 'metalogic' (Peck and Tickell, 2002), or 'constitutive connections and family resemblances' (Peck and Theodore, 2012: 183-184) between distinct and contextually specific instances of neoliberalisation? Section three presents indicative evidence suggesting that the involvement of labour in the development of neoliberalism is not an Australian-specific phenomenon, and that the political and industrial wings of the labour movement were active in constructing the early phases of neoliberalisation in both Britain and the USA, where, most accounts tend to assume, neoliberalism's origins lie instead in the election of the conservative governments of Thatcher and Reagan. In doing so this article aims to 'make arguments that urge the reader to see old problems in a new light' (Skocpol, 1979).

\section{Dominant narratives of neoliberalism}

While recent literature argues neoliberalism takes diverse forms (Brenner et al., 2010; Harvey, 2005), critical accounts of vanguard neoliberalism often privilege a particular narrative as to its origin and development. This narrative posits that the global origin of neoliberalism was its implementation via governments of the Right (in Chile, New York City, the UK and US) and that only subsequently did social democratic parties adopt it. Moreover, neoliberalism is viewed predominantly as a coercive project, involving direct state compulsion, defeat of trade union resistance through iconic confrontations, imposition of structural adjustment in the global South, and use of shock or crisis to impose change. This section substantiates the claim of a dominant narrative through examining two influential accounts: David Harvey's seminal and highly cited analysis in A Brief History of Neoliberalism (2005) and Naomi Klein's widely read account in The Shock Doctrine (2007). The article then turns to a consideration of the 'Accord' in Australia, the examination of which, we argue, suggests the need to rethink the accuracy of the dominant interpretation of neoliberalism and its origins. 


\section{David Harvey: A Brief History of Neoliberalism}

In $A$ Brief History of Neoliberalism David Harvey argues that neoliberalism is a project to restore class power, made possible by capital and national states, in the wake of global economic crisis and social conflict of the 1960s and early 1970s. Harvey's account of vanguard neoliberalism is principally the story of neoliberalism's development in Chile, through to the New York City Council fiscal crisis, and then by the conservative governments led by Ronald Reagan in the USA and Margret Thatcher in the UK. These four locations form the cornerstone of his investigation. He argues that, inspired and influenced by the intellectual efforts of the Mont Pelerin Society and University of Chicago economists, Reagan and Thatcher led governments that implemented the neoliberal shift in two of the largest economies globally. Reagan and Thatcher 'seized on the clues they had (from Chile and New York City) and placed themselves at the head of a class movement that was determined to restore its power' (2005: 63) across the globe. They 'plucked from the shadows of relative obscurity a particular doctrine that went under the name of 'neoliberalism' and transformed it into the central guiding principle of economic thought and management' (Harvey, 2005: 2). Harvey argues the 'first experiment with neoliberal state formation' in Chile, in the wake of the Pinochet coup on 11 September 1973, was achieved through the US's central role in overthrowing the Allende government and the influence of 'the Chicago boys' when they were 'summoned to help reconstruct the Chilean economy' (2005: 8). He contends that while a map of neoliberalisation is difficult to construct because of the only partial progress made in most countries, nonetheless 'the UK and the US led the way' (2005: 88).

Harvey draws a distinction between the introduction of neoliberalism by dictatorships (in Chile and Argentina specifically), and its democratic introduction after 1979 by Thatcher and Reagan. He argues the introduction of neoliberalism in those locations was achieved through the construction of consent, and draws on Gramsci's notion of 'common-sense' to argue consent was developed through various ideological and cultural mechanisms constructed on the material 
basis of the experience of daily life under capitalism in the 1970s (Harvey, 2005: 40-41). Central to his analysis of how consent was constructed, however, are acts of state coercion. Harvey sees the disciplining of labour by Thatcher and Reagan through economic policy and the provocation of major industrial disputes as fundamental to their ability to introduce neoliberal reforms. Reagan defeated the PATCO union when he fired 11,359 striking air traffic controllers and jailed their union leaders in 1981, despite promising in 1980s to work cooperatively with the union (who supported his election) over industrial and safety matters (Harvey, 2005: 25, 59). In March 1984 Thatcher provoked a confrontation with the National Union of Mineworkers, by announcing a wave of redundancies and pit closures (Harvey, 2005: 59). The strike lasted for a year, until 5 March 1985, and despite widespread public support for the striking miners, was won by the Thatcher government (Davidson, 2010: 36-37; Harvey, 2005: 59). Thus, although Harvey argues the introduction in the US and UK was based on consent vis a vis the introduction under the Chilean and Argentinean dictatorships, it is a narrative that simultaneously argues that labour in both locations had to be disciplined and their unions defeated, coercively, as part of the establishment of neoliberalism in those countries.

Harvey argues that following the introduction of neoliberalism in these locations, all states have 'embraced, sometimes voluntarily and in other instances in response to coercive pressures, some version of neoliberal theory and adjusted at least some policies and practices accordingly' (2005: 3). He assigns, for the largest part, a passive role to social democratic parties, and makes only limited reference to neoliberal reforms introduced by them. Moreover, he does not consider locations where the introduction of neoliberalism in the early 1980s was accomplished by such political formations — such as its implementation by labour governments in Australia and New Zealand (July 1984 - November 1990). Further, in Harvey's discussion of the Third Way approach of the governments of Tony Blair and Bill Clinton, on the one hand there is emphasis on the passivity of social democratic formations whilst on the other an emphasis on the policy 
constraints faced by such parties in the wake of the implementation of neoliberalism by earlier governments of the Right. Harvey argues that the greatest testimony to the success of neoliberalism in democratic countries is that it resulted in the more progressive governments that followed Reagan and Thatcher finding 'themselves in a situation where their room for manoeuvre was so limited that they could not help but sustain the process of restoration of class power even against their own better instincts' (2005: 62-63). He argues that the 'genius [of Reagan and Thatcher] was to create a legacy and a tradition that tangled subsequent politicians in a web of constraints from which they could not easily escape. Those who followed, like Clinton and Blair, could do little more than continue the good work of neoliberalisation, whether they liked it or not' (2005: 63).

Harvey typically frames the struggles against neoliberalism by the labour movement as a valiant but unsuccessful opponent of the inexorable realities of the neoliberal era and the power of states and capital (2005: 198-201). At only one point in A Brief History does he criticise the movement itself, for 'rudderless' direction and 'self-inflicted wounds' arising out of an embrace of identity politics and postmodern intellectual currents (2005: 198). Such rare passages notwithstanding, Harvey's chief narrative is that neoliberalism was imposed upon labour and that Third Way governments inherited an already entrenched neoliberal institutional architecture that had been implemented by conservative regimes, leaving the later-governing social democrats with little choice but to submit to the neoliberal agenda.

Through selective analyses of the rise of neoliberalism in Chile, the USA and the UK, Harvey establishes an ideal-type of the origins and trajectory of neoliberalism. This ideal-type narrows our understanding of neoliberalism and its diverse manifestations. It posits social democratic governments as forms of rule unable to manoeuvre outside the constraints of an already established neoliberalism, and eschews the role of the Labour parties of New Zealand and 
Australia — and the labour movement in the case of the latter — in developing and implementing neoliberalism in the early to mid-1980s.

\section{Naomi Klein: The Shock Doctrine}

Naomi Klein's description of the development of neoliberalism in The Shock Doctrine (2007) argues that nation states have used disasters of various kinds to transform society and implement neoliberal policies. As a guide to how neoliberalism was rolled out in practice she cites Milton Friedman's argument that 'only a crisis — actual or perceived — produces real change [and that when] a crisis occurs, the actions that are taken depend on the ideas that are lying around' (Friedman, 1962: xiv; Klein, 2007: 140). Klein 'sees neoliberalism as the manifestation of the inner logic of corporate capitalism and "shock" as the means by which it can be realised" (Davidson, 2010: 16). For Klein, such shock therapy is part of a political 'counter-revolution' against the Keynesianism and social 'compromise' effected during the long boom. She provides an ideas-centred account of neoliberalism, where Friedman and those trained in the neoclassical tradition worked within governments and used political and economic crisis, as well as natural disasters, in order to implement and extend neoliberal restructuring.

Klein argues the origins of neoliberal 'shock-therapy' are to be found in the 'laissez-faire laboratory' of the Pinochet coup in Chile in 1973 (2007: 75-87). Similarly to Harvey, she sees the implementation of neoliberalism by Thatcher as a process of its transition to a democratic footing — and argues neoliberalism, eventually hated by the British public, was 'saved' by the manufactured shock of the Falklands War (Klein, 2007: 131-141). Klein also examines the rise of 'disaster capitalism' through the late 1980s and up to the present through various other shocks including natural disasters like Hurricane Katrina, the disintegration of the Soviet Union after 1989, and the invasion and wars in Iraq and Afghanistan. Prominent in Klein's account is her observation that neoliberalism does not enjoy common assent and it has come about by a 
coercive process of forcing economic change on populations at moments where social resistance is unlikely to develop. For Klein, neoliberalism is to a significant extent built on secret and hidden processes.

There are a number of problems with Klein's approach, some of which result from her acceptance of the dominant narrative as to how neoliberalism is introduced and others which result from her thesis of 'shock' as turning points (Krinsky, 2011). In understanding neoliberalism as the ideological defeat of Keynesian ideas (Klein and Smith, 2008: 584), she limits her analysis to those locations where New Right governments enacted it in the 1970s and 1980s. This fails to acknowledge how neoliberalism was introduced by social democratic parties in the vanguard neoliberal era, but also fails to explain examples of crisis after WWII where neoliberalism was not implemented (Davidson, 2009: 168). In the case of the former she fails to account for why neoliberal restructuring took place in some locations without shocks (such as Australia), and in the case of the latter why greatly different economic policies were followed in various US backed coups (e.g. Indonesia in 1965 in comparison to Chile in 1973). While Klein usefully highlights how politics can shift quickly in situations of social crisis, this is more generally true of the history of capitalism and fails to provide specificity to an understanding of the development of neoliberalism.

\section{Destabilising the dominant narrative}

In according analytical primacy to the experience of Reaganism and Thatcherism, and seeing neoliberalism as involving a transmission from the Global North to the Global South, scholarly analysis has, we argue, narrowed how we understand neoliberalism. The tendency detected by Brenner, Peck and Theodore (2010: 189) with respect to the interpretation of neoliberalism within the varieties of capitalism literature is true of the dominant narrative in critical examinations of neoliberalism more generally, whereby, in treating 'neoliberalisation in ideal- 
typical terms, as a national regime type, it offers little analytical insight into the evolutionary trajectories of neoliberalising reform projects and their institutional expressions'.

Following Connell and Dados (2014), we contend scholarly understanding of neoliberalism can be enhanced by looking at the development of neoliberalism in locations and actors outside those that dominate current accounts. We posit that, when alternative stories of the development of neoliberalism are examined, a different set of neoliberal dynamics is illuminated.

One such dynamic, we contend, is the active and consensual role of labour in the production of neoliberalism in the period of the late 1970s and 1980s. The next section examines one case in which the active role of labour in the construction of neoliberalism seems clear - Australia's longest period of social democratic government between 1983 and 1996. Yet this case is one that is ignored by Harvey and Klein, and certainly doesn't fit within the ideal type that emerges from their accounts of the origins and development of neoliberalism. In turn, our analysis highlights 'the strategic role of national, regional and local state apparatuses as active progenitors of neoliberalising institutional reforms and prototypes, and as arenas in which market-oriented, regulatory experiments are initiated, consolidated and even extended' (Brenner et al., 2010: 196).

\section{Neoliberalism and labour in Australia}

At the 1983 Australian federal election the ALP won office in the depths of the worst economic crisis since the Great Depression, and set about radically changing the political economic landscape. The Labor government implemented a bipartite social contract it had recently signed with the Australian Council of Trade Unions (ACTU), the national trade union federation. The agreement immediately halted wage growth by indexing it to inflation, and agreed to protect living standards through enhancement of the social wage. Simultaneously, the ALP instigated a 
series of vanguard neoliberal policies including financial deregulation and the floating of the national currency. These processes are predominantly understood in the scholarly literature as counter-posed and antithetical corporatist and neoliberal projects (Ahlquist, 2011; Peetz, 2013; Spies-Butcher, 2012). In contrast, however, the argument developed here is that there was a concord, or harmony, between these two transformative policy regimes. We posit that the social contract was the form neoliberalism took in Australia in its initial phase. In this section we overview how neoliberalism became hegemonic through the Accord, with a focus on its consensual implementation. We argue that neoliberalism resulted not from a failure or inability of the trade unions to fight its progress in Australia, but rather that neoliberalism was embedded within the corporatist project and actively constructed by both the industrial and political wings of organised labour.

\section{The content of the Accord and Australian neoliberalism}

The Statement of Accord Between the Australian Labor Party and the Australian Council of Trade Unions Regarding Economic Policy ('the Accord') was the 'primary statement of domestic economic policy' during the 13 years of Labor government between 1983 to 1996 (Ahlquist, 2011: 133). In return for real wages remaining static through centralised wage indexation, the Accord promised to hold down prices and non-wage incomes and institute social wage improvements and tax reform — 'a framework of policy measures directed at alleviating unemployment and redistributing income and wealth to the less well-off (ALP \& ACTU, 1986). Its aim was to promote economic growth through central coordination and simultaneously reduce inflation and improve living standards through an increased social product.

The Accord contained an agreement upon policy details that can be described broadly as interventionist, expansionary and progressive. This included: moderation of prices, wages and non-wage incomes; a commitment to improved working conditions and progressive industrial 
relations legislation; socially equitable taxation; increased government expenditure; industry development policy; improved social security benefits; and, progressive education and health reforms. The parties argued it would be through consensual planning that the Accord 'would enable attainment of currently unobtainable objectives' (ibid) of growth, full employment and lower inflation. Living standards would be improved immediately through an expanded social wage, and over time through compensation 'to reflect the distribution of improved output as measured by national productivity' (ibid).

Prima facie, then, the Accord seems a long way from neoliberalism, and indeed, a repudiation of some of the kinds of neoliberal policies being pursued contemporaneously by conservative governments in Britain and the USA. Certainly, this is how it has most often been reviewed, indicative of which is Wright's (2014: 6) assessment that 'the Accord represented a more equitable alternative to the neoliberal approaches of the Thatcher government and its counterparts in the United States and New Zealand and elsewhere'. As will be demonstrated, however, the Accord proved central to the extensive neoliberalisation of the Australian state and economy during the decade and a half of Labor governance.

The Accord was reconstituted through national wage cases and renegotiated terms between the parties over the next 13 years, in eight 'editions' (Mark I-VIII). The editions quickly narrowed to focus almost exclusively on wages, culminating in the radical industrial reforms of 1993 that abolished much of the centralised wage process and introduced enterprise bargaining. A limited number of social wage promises were delivered (Hancock, 2014: 280), most particularly the reinstitution of universal or moderate cost access to most health services and the extension of the superannuation compulsory retirement savings scheme to the whole workforce from 1992. Conversely, many significant policy elements were not implemented including: the maintenance of real wages; action on moderating prices and non-wage incomes; progressive taxation; and, 
public expenditure increases at pledged levels. In fact, adjusted for inflation public expenditure increases were less than those delivered by the conservative governments that preceded and followed this ALP government (Laurie and McDonald, 2008).

Shortly after the election of the ALP government the policy framework departed from that set out in the Accord. In the month after Labor's 1983 victory it convened a national economic summit, and the resultant 'tripartite' communiqué moved away from the commitments between the ALP and ACTU (Stilwell, 1986: 11-15). In the same period the government also signed a free trade agreement with New Zealand, titled the Closer Economic Relations Agreement, undermining a promise to consult with Australian Metal Workers and Shipwrights Union given its impact on the sector (Carmichael, 1983). By the end of the year the government had floated the Australian Dollar, and within two years the banking sector had been deregulated. As Bowden (2011: 69) notes, 'the new government adopted a neo-liberal agenda'. Crucially, in the second year of the Accord the Government adopted a framework it termed 'the trilogy'. This committed the government not to increase taxation, government expenditure, or the size of the budget deficit, as a percentage of gross domestic product. The trilogy was a 'self-imposed fiscal straightjacket' (Stilwell, 1986: 15) and sharply moved from the expansionary commitments and social wage promises of the Accord. As the period progressed, free tertiary education was abolished and taxation, which was to be progressively reformed to ensure corporations paid a 'fair share', moved in the opposite direction. Other neoliberal measures implemented by Labor and often supported by the union leadership included restrictive monetary policy, extensive industry deregulation, privatisation of public assets, corporatisation of government departments, dismantling of tariff protections and promotion of 'free trade', tendering for previously publicly provided services, and the increased targeting of welfare assistance. Throughout this period, industrial activity declined markedly partly due to the Accord's centralised negotiations, but also because the ACTU policed member unions to comply when attempts were made by workers to 
move outside the centralised wage indexation as real wages fell (McEvoy and Owens, 1990; Sheehan and Jennings, 2010: 145-194). Under the Accord the income and wealth gap between the most and least well off also widened (Frijters and Gregory, 2006). Thus, by the end of Australia's longest ever period of social democratic governance, a radical neoliberal restructuring of the state and economy had been affected and it was at least as nationally far-reaching as the contemporaneous neoliberal changes made under Reagan and Thatcher.

Certainly this did not follow the same temporal sequence, nor did it assume that same form, as the neoliberal transformations presided over by conservative regimes in Britain or the USA. Yet this perhaps merely underscores the uneven and 'variegated' (Brenner et al., 2010; Macartney, 2010) character of 'actually existing neoliberalism' (Brenner and Theodore, 2002; Cahill, 2014; Peck and Tickell, 2002; Wacquant, 2012). Nor did it follow the fundamentalist prescriptions of neoliberal theorists such as Milton Friedman and Friedrich Hayek. Yet, as several authors have highlighted (Cahill, 2014; Peck and Tickell, 2002), it is important to distinguish between the normative ideals of neoliberal theory, and the ways in which neoliberal transformations have manifested in practice. Therefore, that the roll out of neoliberal policies in Australia was implemented alongside the construction of institutions (such as Medicare and corporatism) that would seem anathema to doctrinaire neoliberals, is not sufficient reason to regard the Accord period as a break with neoliberalisation.

\section{Labour's active role in neoliberalism in Australia}

The Accord is predominantly viewed in the scholarly literature as a form of corporatism and a method of economic management distinct from, and in competition with, neoliberalism. This is true even of many analyses that are critical of the Accord for its failure to implement its promised reforms. In contrast however, we argue that although the Accord was a corporatist framework, fitting the archetype outlined by Leo Panitch $(1977,1981)$, it was nonetheless part of 
the form that neoliberalism took in Australia and central to the roll-out of neoliberal policies. In reflecting on the corporatist experience in Europe after the Second World War, Panitch argued that in 'virtually every liberal democratic country in which corporatist structures become at all important an incomes policy designed to abate the wage pressure of trade unions was the frontispiece of corporatist development' (1977: 74). It is here, in the efforts of corporatism and neoliberalism to increase labour exploitation, that we locate one of the key points of concord between the Australian social contract and neoliberalism.

While some of the literature on the Accord acknowledges and discusses the extensive neoliberal reforms undertaken by the ALP government, the Accord has been predominantly posited as a social-democratic exercise mobilised or buttressed against such policies. It has been understood as an alternative economic plan designed to, in various combinations: a) buffer the advance of neoliberalism at a time of protracted economic crisis and in a period in which resistance was not possible or could not possibly succeed; b) protect worker's wages and enhance the social wage in lieu of wage increases as the economy recovered; and c) limit the growth of inequality compared to others nations implementing neoliberalism in the 1980s.

For example, Spies-Butcher argues that it was an approach where 'collaboration combined with a more pragmatic approach to "economic rationalism" [a common Australian synonym for neoliberalism]' and that the ALP achieved 'a pragmatic accommodation between markets and equity' (2012: 208). Peetz similarly argues that the period was one with 'no uniformity of thought...[and where] market liberalism and the modified Keynesianism of the Accord' competed for choice in policy development. The political process was such that 'sometimes one idea won out, sometimes the other idea did' (2013). 
Cottle and Collins (2010: 34) also deny that Labor's transformations of the state amounted to a form of neoliberalism. Rather, they argue that because the Labor government's radical transformations of the state and economy were 'carried out with the formal approval of the peak representative body of organised labour', and because the Accord agreements did not contain any formal commitments to 'the class goals of capital expressed in radical neoliberal ideology' that the period is better described as 'Neo-Laborism, the pragmatic regulatory logic which reconciled the conflict between laborism and electoralism which had plagued all former ALP governments in office'.

Pierson makes a closely related point when he argues that although the 'reputation of the ALP under [successive Labor Prime-Ministers] Hawke and Keating [was] as the first neoliberal labour government', this judgement is 'too straightforward' (2002: 184). He argues that while 'Canberra's policy making and opinion formation did come increasingly under the direction of "economic rationalists", there was not the "wholesale assault upon welfare provision that marked out neoliberal governments (at least in aspiration) elsewhere' (ibid 2002: 184). Pierson thus characterises the Accord period as 'social democracy on the back foot'. Nonetheless, Pierson questions, whether the differences between Australia and its counterparts — in Thatcherism, Reaganism and Rogernomics — offer, quoting Wiseman, 'only the prospect of a "kinder road to hell"”(2002: 188). Ultimately Pierson concludes that the differences in policy implemented by Hawke and Keating and 'the real neoliberals' that succeeded them in the Coalition Government, are 'not unambiguously differences of kind rather than of degree' (2002: 196). While Pierson recognises neoliberal elements within the policy program of successive Australian Labor governments, he is nonetheless reluctant to identify those governments as 'neoliberal' because this label — to his mind it would seem — should be reserved for governments of the Right. Thus Pierson's analysis accords with the dominant narrative regarding the development of neoliberalism: that 'real' neoliberalism is to be located in Reaganism and 
Thatcherism, against which other paths to neoliberalism are adjudicated. When this assumption that neoliberalism is, first and foremost, a project of governments of the Right which is then imposed on civil society, is set aside, then the commonalities between the introduction in Australia, the US and the UK come into sharper focus.

\section{The Accord as neoliberalism}

In contrast to those accounts which separate the Accord from neoliberal transformation in Australia, some authors argue that the 'formal' social contract also included an 'informal Accord' and that this facilitated the introduction of neoliberalism in Australia. The 'informal Accord' denotes the support given by the unions to the ALP, and the willingness of the unions to significantly compromise their political objectives to ensure 'their' government remained in power. Bramble and Kuhn (1999) highlight how 'the formal and informal aspects of the Accord was to manage the neo-liberal transformation of state and economy by tying the leadership of the labour movement to this process' (ibid 2008: 326). This approach has the advantage of understanding the wider political context and processes behind the Accord. The willingness of the ACTU and union officials to support the ALP, despite their concerns over the direction of government policy, constituted a submission to neoliberalism. Concurrently, the ACTU and leading unions also engaged in silencing dissent to the Accord framework and wider neoliberal reforms — either by actively working to prevent industrial action or by failing to assist and defend unions when they took industrial action. While the most prominent of these were the Pilots' Dispute, where the ACTU acquiesced to the government's use of the military as strike breakers, and the deregistration of the Builder's Labourers Federation, such disciplinary measures were also imposed by the ACTU upon their members in various other industrial disputes (McPhillips, 1985). 
However, while the informal Accord framework emphasises how the Accord facilitated the development of neoliberalism by tying the unions to the Government's priorities, it is also possible to take this argument further. The Accord institutionalised the trade union leadership within the apparatuses of the state. Through the Accord, the ACTU leadership enjoyed an 'unprecedented level of direct influence... over the policy process' (Wright, 2014: 3). It was incorporated into the state through corporatist bipartite and tripartite bodies and, more broadly, it was incorporated in to the political project of neoliberalisation. The goal of this project was to restore conditions for profitable capital accumulation in response to the crisis that has beset the Australian and global capitalist economies since the 1970s. Certainly, as Collins and Cottle argue, this may have been born more of 'pragmatism' than ideology, but it was, nonetheless, clearly neoliberal in nature. In Australia, the union leadership played a central and active role in this project.

One important way in which this occurred was industry development and technological change processes. The original social contract agreed to implement comprehensive industry development policy, with the 'paramount objective' being the 'attainment of full employment' through 'interventionist' industry planning. In practice, clauses related to keeping tariff protections were ignored and policy and funding was directed at technological adjustment to ensure industries were 'viable' in an increasingly less protected environment. In the case of the impact of the steel plan in Wollongong, for example, a focal point for both union militancy and the serious effects of unemployment in the midst of the crisis, the government and 'the ACTU accepted BHP's long-term strategy and supported the provision of hundreds of millions of taxpayers' dollars to the company to invest in job-displacing technology' (Southall, 2006: 9). As Julianne Shultz put it, the industry plan for steel was in fact a process to restructure the industry in Wollongong in accordance of the wishes of the major employer, BHP. Thus, 'when [Prime Minister Bob] Hawke spoke of saving the steel industry, it was the salvation of the balance sheet 
he was talking about, a balance sheet that made no provision for the social impact of the restructuring' (Schultz, 1985: 252). Although local unions fought the plan, they were ultimately brought in to line by the central union leadership and the threat of mass sackings in a town already ravaged by unemployment. Industry policy was, ultimately, a process that placed the unions inside the state efforts to restructure the economy along neoliberal lines.

The Accord constructed a new form of political rule in the wake of the economic and social upheavals of the 1970s. Australian neoliberalism was constructed consensually, as a shared national project of economic management and political economic transformation, and involved labour directly through the trade union leadership. Neoliberalism in Australia was sold to the electorate as a positive consensual project of efficient economic management in the era of globalisation. Hancock's (2014) identification of the crucial role played by the ACTU's 'strong leadership' in ensuring that wage repression was achieved 'without major resistance' is applicable to the Accord's role in the process of neoliberalisation more generally. It is not simply that the Accord assisted the introduction of neoliberal policies through its various effects, although it did have that result (see for example Buchanan et al., 2014: 301). Rather it is to argue that the agreement also embedded a consent for the neoliberal project to take place, with the Accord significantly weakening industrial solidarity leading to 'not just deepening wage inequality, but the isolation of unions from a workforce increasingly subject to the vagaries of the market') (Buchanan et al., 2014: 302). Dissent against the Accord and neoliberalism were not absent (see Strauss, 2013), rather, the ACTU's active support for the neoliberal restructuring of the Australian state and economy, and the acquiescence of leading unions, ensured that such dissent remained marginal. The Accord and vanguard neoliberal reforms were not exogenous; rather the Accord was the form that the mode of neoliberal rule took in Australia.

\section{Labour and neoliberalism internationally}


So far it has been argued that labour — through the organisational leadership of the labour movement and the Labor Party — was a key force within the state that made neoliberalism in Australia, and that this occurred contemporaneously to the better-known examples of neoliberalisation carried out by the conservative Thatcher and Reagan administrations. This is in contradistinction to the dominant narrative regarding the rise of neoliberalism, which, generalising from the experiences of the Thatcher and Reagan regimes, posits that neoliberalism was imposed by conservative governments upon labour. The task now remains to ascertain whether the analysis presented of the development of neoliberalism in Australia is also applicable to other countries. Is it a uniquely Australian phenomenon or does it, instead, prompt a re-think of the narrative of neoliberal development and labour's role within this, in other countries too?

The most obvious example that suggests the Australian case study might be more generally applicable is that of its close neighbour, New Zealand. Here, there was a contemporaneous process of neoliberalisation driven by that country's Labour Party in office (Kelsey, 1995, 2014; Roper, 2005). However, some might be inclined to attribute the parallel labour-driven neoliberalisation in Australia and New Zealand as deriving from Antipodean exceptionalism and as not being relevant for an explanation of the development of neoliberalism in the core capitalist countries. For the argument that labour made neoliberalism to have utility as an interpretive frame for understanding the dynamics of neoliberalism more generally, evidence would need to be found that labour was active in the creation of neoliberalism in the neoliberal heartlands of Britain and the USA, as well as in the antipodean periphery.

In what follows we offer two broad examples as indicative evidence that labour was indeed an agent in the creation of neoliberalism in the core capitalist countries of the USA and Britain. Our argument is that labour's active creation of neoliberalism in these countries pre-dates the well documented role that successive 'third way' New Labour governments played in the 
neoliberalisation of Britain from 1997-2010, and that the Democratic Presidency of Bill Clinton played in extending the process of neoliberalisation within the USA and indeed, throughout the global economy from 1993-2001. Indeed, the evidence we present below is indicative of labour being an agent in the roll out of neoliberalism prior to the Thatcher and Reagan administrations that have most often been identified as being in the vanguard of processes of neoliberalisation.

\section{Labour and the development of neoliberalism in 1970s USA}

One early instance of the roll out of neoliberalism in the USA was the Airline Deregulation Act of 1978. It was driven and signed into legislation by Democratic President Carter. Occurring prior to the better known neoliberal policies of the Reagan administration it has been described as 'the first major rolling back of the New Deal' (Yergin and Stanislaw, 1998: 345). Moreover, it was President Carter who appointed Paul Volcker as the Chairman of the Federal Reserve Board, and it was during Carter's term that the 'Volcker shock' began, as did the Fed's experiment with monetarism, both considered to be key elements of the neoliberal agenda in the USA (Harvey, 2005: 1-2).

Nonetheless, despite the integration of organised labour within the US Democratic Party, it might be objected that the Democrats are not truly a 'party of labour', and therefore that such examples of neoliberalisation as occurred under the Carter regime fail to make the case sufficiently that labour helped to make neoliberalism.

Concurrently, however, there were other developments within organised labour in the USA that provide indicative evidence supporting the thesis that labour was an active agent in the creation of neoliberalism. A striking feature of the political and economic landscape of the USA from the late 1960s, and extending through much of the 1970s, was the significant upsurge in labour militancy. It was, as Aaron Brenner argues, 'one of the largest strike waves in US history, during 
which workers twice set records for the number of strikes in a single year' (2010: xi). Perhaps even more noteworthy is that many such examples of militancy were of a 'wildcat' nature (i.e. they were not endorsed by the official trade union leadership).

One possible explanation for the rise of neoliberalism in the USA, and indeed, elsewhere, is that neoliberalism was the response by employers and state elites to these mobilisations, and the means through which management was able to re-establish effective control over workplaces, and lower real unit labour costs in an era of intensified international competition. Alongside this, however, a different but complementary explanation of the rise of neoliberalism is possible.

As Kim Moody argues, at the end of the 1970s, trade union leaders in the USA began to respond to the militant, wildcat upsurge from the broader trade union membership and 'resisted the assault from the ranks on bureaucratic rule and increasingly sided with management in the restoration of workplace-authority and company-competitive priorities' (2012: 6). As part of this response, union leaders struck deals with employers which eroded both the wages and working conditions of members. Crucial to this process, according to Moody, was the deal struck between the United Auto Workers and the management of the Chrysler Corporation 'which opened the floodgates of concessionary bargaining' (2010: 142). Importantly, this occurred both before the Carter government's bailout of Chrysler, and before the more iconic PATCO dispute (op cit 2012: 6-7), in which the Reagan government was instrumental in defeating the strike by air traffic controllers, and which is most often singled-out in progressive accounts of the rise of neoliberalism in the USA.

The labour movement therefore helped to make neoliberalism in the USA through its concessions to employers that ushered in the new template of lean production, granting management greater prerogatives over the labour process, a hallmark of the neoliberal era, as 
well as contributing to working class austerity. That this was a result of the imposition of neoliberalism upon the working class, and of defeats of the working class by capital and the state is not in question. What we are suggesting, in contrast, and in parallel, is that labour movement leaders were complicit in processes of workplace neoliberalisation through undercutting the organic mobilisations by workers against capital at the time, in the interests of maintaining or resecuring the power and control of trade union leaders within and over the institutions of organised labour. It was thus essentially a 'political choice' (Moody, 2012: 6) by the labour movement leadership, not simply their defeat at the hands of capital, nor simply the imposition of austerity from above (important though both of these factors were), that ushered in processes of neoliberalisation in the USA from the 1970s onwards.

\section{British labour and neoliberalism, 1974-1979}

While the most radical and far-reaching neoliberalisation of the British state and economy undoubtedly occurred under the eleven years of the Prime-ministership of Margaret Thatcher, its antecedents are to be found in the actions of sections of the labour movement during the 1970s.

Writing of the period of Labour in government from 1974-79, McIlroy argues that 'scrutiny of Labour policies illustrates the need to see in Thatcherism continuity as well as change' (1995: 192). It was a period during which successive Labour governments responded to the twin challenges of a global economic crisis and the growing transnationalisation of capital, with austerity programs on the one hand, and proposals for a radical extension of social democracy and nationalisation on the other (Lambie, 2013). While the latter programme was more aspirational than real, it was the former austerity measures that provided some of the material policy precursors for the more widespread neoliberalisation of the Thatcher years. 
Labour's austerity agenda included cuts to social spending, later combined with wage suppression. While it was the Parliamentary Labour Party that was directly responsible for the savage cuts to social expenditure, the agency of the labour movement leadership more broadly in such decisions is clear. Beyond the dominance enjoyed by trade unions at annual Labour Party national conferences, in 1972 a formal Trade Union-Labour Party liaison committee was developed which shaped subsequent policy (McIlroy, 1995: 187). With respect to wage suppression, the role of the trade union leadership was much more overt, joining with the labour government in an agreement to limit wage rises — 'The Social Contract' — to below the rate of inflation. This led to a generalised decline in real wages during the first three years of Labour's period in office, and was described by Panitch (1981: 38) as 'the most sustained and draconian reduction of real wages... in the post-war period'. Indeed, it was only when trade unions began to break from the Social Contract in 1977 that real wage gains were made.

Nor should it be imagined that labour leaders were forced into such neoliberal measures by the need to secure IMF stabilisation funds. Certainly, there was pressure from the IMF for the Labour government to pursue a neoliberal macroeconomic agenda. Nonetheless, there was considerable internal dissent within the Labour Party and the labour movement more generally to the government's neoliberal austerity agenda. Significant sections of the movement coalesced behind radical social democratic/socialist forms of crisis response (Lambie, 2013). Moreover, the later admission by Callaghan in a BBC interview that the 'IMF was a useful screen' — by which he goes on to clarify that the conditionalities of the IMF gave the government cover for the austerity program they felt necessary to implement anyway — suggests that he, and perhaps others in the Cabinet, felt neoliberal measures were necessary and enacted independent of any pressure brought to bear by the IMF (Cockerell, 1992). Indeed, Callaghan's speech to the 1976 Labour Party Conference was replete with statements that anticipated those made in subsequent 
years by his successor, Margaret Thatcher (Callaghan, 1976). As Lambie writes of the government's 1976 'IMF' austerity' program,

This monumental decision on the part of a major power, to acquiesce to the discipline of what were ultimately private capital interests was a defining moment in the development of globalisation and the rise of neoliberalism. It was also a serious blow to any aspiration of promoting democratic socialism in Britain (2013: 355).

The period of 1974-1979 when Labour was in government in Britain thus presents a parallel with the period of Labor in government in Australia during the 1980s made 1990s. In each case the leadership of organized labour subordinated the immediate interests of its membership in the interests of maintaining support for a labour government. However, while this pattern largely continued (with a few notable exceptions, as discussed earlier) throughout the entire thirteenyear period of Labor in office in Australia, in Britain this pattern was broken — temporarily at least — by the 'Winter of Discontent', when trade unions pursued higher wage outcomes directly with employers, rejecting the constraints imposed via the Social Contract. Moreover, it should be noted that, unlike in Australia during the Accord years, the Labour Party in Britain had, during its period in office, official commitments to a quite radical economic agenda. Indeed, after its election defeat at the hands of Thatcher in 1979 it turned even further to the Left. Yet, this was to prove a hiatus in the British Labour's march towards neoliberalism. Labour's disastrous election result of 1983 paved the way for the rise of Neil Kinnock, under whose leadership the party embarked on a strategy of 'breaking labour from the lurch left and accepting key points of Thatcherism' (McIlroy, 1995: 211). In longer view then, Lambie's conclusion about the significance of Labour's austerity agenda of the 1970s seems apposite: 'Henceforth there was little opposition to the dismantling of the post-war consensus that followed when the 
Conservatives came to power under Thatcher in 1979... The election of Blair in 1997 marked the success of that project' (2013: 357).

By examining these three geographically and temporally specific instances of neoliberalisation, important 'family resemblances' emerge. In each instance, labour movements and labour parties were active in the creation of neoliberalism. To be sure, the particularities of each case were different. Moreover, it might be the case that this was a phenomenon unique to 'uncoordinated liberal market economies' which, due to similar inherited institutional architectures, 'were less well equipped organisationally and institutionally than were coordinated market economies to manage the crisis-tendencies of Atlantic Fordism, and... provided more fertile ground for the rise of neoliberalism (Jessop, 2002: 457).

Nonetheless, it prompts a re-evaluation of the nature of, and forces driving neoliberalism more generally. This method follows the spirit of McMichael's strategy of 'incorporating comparison', whereby, through bringing otherwise disparate, temporally and geographically distinct moments within the word capitalist system into comparison, 'in effect the "whole" emerges via comparative analysis of its "parts" as moments of a self-forming whole', which 'give[s] substance to a historical process' (1990: 386) .

In this case, the re-examination of what has generally been considered to be either an exception to the dominant narrative of neoliberalism's development, or at least an incomplete fit Australia from 1983-1996 - suggests the presence of a hitherto obscured agent in the roll-out of neoliberalism in that particular context. By bringing this into comparison with those countries often held to be exemplars of the neoliberal transformation, a new dimension to the 'origins of neoliberalisation processes in the wake of the systemic crisis of the Keynesian geoinstitutional order' (Brenner, Peck and Theodore 2010: 217). 


\section{Conclusion}

This article has argued that the dominant narrative regarding the development of neoliberalism misses the way that neoliberalism developed in Australia. There, from 1983 until 1996, the leadership of the political and industrial wings of the organised labour movement were in the vanguard of the roll out of a process of radical neoliberalisation. The article has also suggested that there is evidence that labour played an active role elsewhere in the early phases of the creation of neoliberalism, in those very countries in which the dominant narrative frames neoliberalism as being imposed upon labour by New Right political forces. Clearly this suggests that the dominant narrative regarding the role of conservative parties in the implementation of neoliberalism should be augmented by an analysis that recognises not only the ways that labour movements tried to resist neoliberalism, but also the ways that labour movements and parties were active agents in the construction of neoliberalism. Viewing the development of neoliberalism in this way also prompts reconsideration of what the central forces were that drove the development of neoliberalism, and what forces labour parties and movements were responding to that led them to pose neoliberalism as the solution. Whereas many accounts of the rise of neoliberalism have looked to the influence of fundamentalist neoliberal ideas articulated by various think tanks and intellectuals as the explanation for the neoliberal policy revolution, this account would seem more difficult to sustain once it is admitted that labour movements and parties, who had little contact with and/or hostility towards such institutions and intellectuals, were key agents of the neoliberal transformation. Given the persistence of neoliberalism in the wake of the 2008 global economic crisis, we argue that a reassessment of the origins of neoliberalism can contribute to a more satisfactory account of the neoliberalism's content, durability and flexibility by better understanding the social forces involved in its construction. 


\section{References}

Ahlquist JS (2011) Navigating Institutional Change: The Accord, Rogernomics, and the Politics of Adjustment in Australia and New Zealand. Comparative Political Studies 44: 127-155.

ALP \& ACTU (1986) Accord Mark I: 1983-84. In: Stilwell F (ed.), The Accord...and Beyond, Leichhardt: Pluto Press Australia, pp. 159-176.

Bowden B (2011) The Rise and Decline of Australian Unionism: A History of Industrial Labour from the 1820s to 2010. Labour History 100: 51-82.

Bramble T and Kuhn R (1999) Social Democracy After the Long Boom: Economic Restructuring Under Australian Labor, 1983 to 1996. In: Upchurch M (ed.), The State and Globalization: Comparative Studies of Labour and Capital in National Economies, London: Mansell Publishing, pp. 20-55.

Brenner A (2010) Preface. In: Brenner A, Brenner R, and Winslow C (eds), Rebel Rank and File: Labor Militancy and Revolt from Below During the Long 1970s, New York, NY: Verso, pp. xixix.

Brenner N and Theodore N (2002) Cities and the Geographies of 'Actually Existing Neoliberalism'. Antipode 34(3): 349-379.

Brenner N, Peck J and Theodore N (2010) Variegated Neoliberalisation: Geographies, Modalities, Pathways. Global Networks 10(2): 182-222.

Buchanan J, Oliver D and Briggs C (2014) Solidarity Reconstructed: The Impact of the Accord on Relations Within the Australian Union Movement. Journal of Industrial Relations 56(2): 288-507.

Cahill D (2008) Labo(u)r, the Boom and the Prospects for an Alternative to Neo-liberalism. Journal of Australian Political Economy 61: 321-335.

Cahill D (2014) The End of Laissez. Faire?: On the Durability of Embedded Neoliberalism. Cheltenham: Edward Elgar.

Callaghan J (1976) James Callaghan: Leader's Speech. Blackpool. Available (consulted 28 August 2014) at: http://www.britishpoliticalspeech.org/speech-archive.htm?speech=174.

Carmichael L (1983) Letter to New Zealand Engineering Union. Amalgamated Metals Foundry and Shipwrights' Union.

Cockerell M (1992) Labour's Last Premier. BBC. Available (consulted 26 August 2014) at: https://www.youtube.com/watch?v=QOn69eukaDU.

Connell R and Dados N (2014) Where in the World Does Neoliberalism Come From? Theory and Society 43: 117-138.

Cottle D and Collins J (2010) Labor Neoliberals or Pragmatic Neo-Laborists? The Hawke and Keating Labor Governments in Office, 1983-96. Labour History 98: 25-37.

Davidson N (2009) Shock and Awe. International Socialism Journal 124: 159-178. 
Davidson N (2010) What was Neoliberalism? In: Davidson N, McCafferty P, and Miller D (eds), Neoliberal Scotland: Class and Society in a Stateless Nation, Newcastle Upon Tyne: Cambridge Scholars Publishing, pp. 1-92.

Friedman M (1962) Capitalism and Freedom. Chicago, IL: University of Chicago Press.

Frijters P and Gregory R (2006) From Golden Age to Golden Age: Australia's 'Great Leap Forward'? The Economic Record 82(257): 207-224.

Hancock K (2014) The Accord, the Labour Market and the Economy. Journal of Industrial Relations 56(2): 273-287.

Harvey D (2005) A Brief History of Neoliberalism. Oxford: Oxford University Press.

Jessop B (2002) Liberalism, Neoliberalism, and Urban Governance: A State-Theoretical Perspective. Antipode 34(3): 452-472.

Kelsey J (1995) The New Zealand Experiment: A World Model for Structural Adjustment? Auckland: Auckland University Press.

Kelsey J (2014) The Neoliberal Emperor has No Clothes: Long Live the Emperor. In: Schroeder $\mathrm{S}$ and Chester L (eds), Challenging the Orthodoxy. Reflections on Frank Stilwell's Contribution to Political Economy, Berlin: Springer-Verlag, pp. 151-172.

Klein N (2007) The Shock Doctrine. Camberwell: Penguin Books.

Klein N and Smith N (2008) The Shock Doctrine: A Discussion. Environment and Planning D: Society and Space 26(4): 582-595.

Krinsky J (2011) Neoliberal Times: Intersecting Temporalities and the Neoliberalisation of New York City's Public-Sector Labor Relations. Social Science History 35(3): 381-422.

Lambie G (2013) Globalisation Before the Crash: The City of London and UK Economic Strategy. Contemporary Politics 19(3): 339-360.

Laurie K and McDonald J (2008) A Perspective on Trends in Australian Government Spending. Australian Government (Treasury).

Macartney H (2010) Variegated Neoliberalism: EU Varieties of Capitalism and International Political Economy. London: Routledge.

McEvoy K and Owens R (1990) The Flight of Icarus: Legal Aspects of the Pilots' Dispute. Australian Journal of Labour Law 3(2): 87-129.

McIlroy J (1995) Trade Unions in Britain Today. 2nd ed. Manchester: Manchester University Press.

McMichael P (1990) Incorporating Comparison within a World-Historical Perspective: An Alternative Comparative Method. American Sociological Review 55(3): 385-397.

McPhillips J (1985) The Accord and its Consequences: Trade Union Experiences. Surry Hills: Socialist Party of Australia. 
Moody K (2010) Understanding the Rank-and-File Rebellion in the Long 1970s. In: Brenner A, Brenner R, and Winslow C (eds), Rebel Rank and File: Labor Militancy and Revolt from Below During the Long 1970s, New York, NY: Verso, pp. 105-146.

Moody K (2012) Contextualising Organised Labour in Expansion and Crisis: The Case of the US. Historical Materialism 20(1): 3-30.

Panitch L (1977) The Development of Corporatism in Liberal Democracies. Comparative Political Studies 10(1): 61-90.

Panitch L (1981) Trade Unions and the Capitalist State. New Left Review 1(125): 21-43.

Peck J and Theodore N (2012) Reanimating Neoliberalism: Process Geographies of Neoliberalisation. Social Anthropology 20(2): 177-185.

Peck J and Tickell A (2002) Neoliberalizing Space. Antipode 34(3): 380-404.

Peetz D (2013) The Lessons of the Accord for Modern Times: Think Outside the Box. The Conversation, 10th June. Available (consulted 10 June 2013) at: https://theconversation.com/the-lessons-of-the-accord-for-modern-times-thinkoutside-the-box-14985.

Pierson C (2002) 'Social Democracy on the Back Foot': The ALP and the 'New' Australian Model. New Political Economy 7: 179-197.

Roper BS (2005) Prosperity for All? Economic, Social and Political Change in New Zealand Since 1935. Southbank Victoria: Thompson.

Schultz J (1985) Steel City Blues: The Human Cost of Industrial Crisis. Melbourne: Penguin.

Sheehan M and Jennings S (2010) A Federation of Pilots: The Story of an Australian Air Pilots' Union. Melbourne: Melbourne University Press.

Skocpol T (1979) States and Social Revolutions: A Comparative Analysis of France, Russia and China. Cambridge: Cambridge University Press.

Southall N (2006) Working for the Class: The Praxis of the Wollongong Out of Workers' Union. Honours, Wollongong: University of Wollongong.

Spies-Butcher B (2012) Markets with Equity? Lessons from Australia's Third Way Response to Neoliberalism. In: Cahill D, Edwards L, and Stilwell F (eds), Neoliberalism: Beyond the Free Market, Cheltenham: Edward Elgar.

Stilwell F (1986) The Accord ... and Beyond. Leichhardt: Pluto Press Australia.

Strauss J (2013) Opposition to the Accord as a Social Contract in the 1980s. Labour History 105: $47-62$.

Wacquant L (2012) Three Steps to a Historical Anthropology of Actually Existing Neoliberalism. Social Anthropology 20(1): 66-79.

Wright CF (2014) The Prices and Incomes Accord: Its Significance, Impact and Legacy. Journal of Industrial Relations 56(2): 1-9. 
Yergin D and Stanislaw J (1998) The Commanding Heights: The Battle for the World Economy. New York, NY: Touchstone.

For correspondence:

Elizabeth Humphrys, School of Communication, University of Technology Sydney, 15

Broadway, Ultimo, NSW, Australia, 2007

Email: Elizabeth.humphrys@sydney.edu.au

Damien Cahill, Political Economy Department, Merewether Building (H04), University of

Sydney, NSW, Australia, 2006

Email: damien.cahill@sydney.edu.au 